\title{
Treponema medium sp. nov., Isolated from Human Subgingival Dental Plaque
}

\author{
TOSHIHIKO UMEMOTO, ${ }^{1 *}$ FUTOSHI NAKAZAWA, ${ }^{2}$ ETSURO HOSHINO,${ }^{2}$ KEIJI OKADA, ${ }^{3}$ \\ MASAHITO FUKUNAGA, ${ }^{3}$ AND ISAMU NAMIKAWA ${ }^{1}$ \\ Department of Oral Microbiology, School of Dentistry, Asahi University, Gifu 501-02, ${ }^{1}$ Department of Oral \\ Microbiology, School of Dentistry, Niigata University, Niigata $951,{ }^{2}$ and Department of Molecular Microbiology, Faculty \\ of Pharmacy and Pharmaceutical Sciences, Fukuyama University, Fukuyama, Hiroshima 729-02, ${ }^{3}$ Japan
}

\begin{abstract}
A new Treponema species, for which we propose the name Treponema medium, was isolated from subgingival plaque from an adult with periodontal disease. The morphological characteristics, differential biochemical characteristics, and protein profiles on sodium dodecyl sulfate-polyacrylamide gel electrophoresis gels of this organism are described. The guanine-plus-cytosine content of the DNA of T. medium is $51 \mathrm{~mol} \%$. The levels of DNA-DNA relatedness of the new species to other Treponema species, including Treponema denticola, Treponema vincentii, Treponema socranskii, Treponema pallidum, and Treponema phagedenis, are less than 30\%. A phylogenetic analysis based on 16S rRNA sequences distinguished the new Treponema strain from strains belonging to previously described Treponema species. The type strain of $T$. medium is strain G7201.
\end{abstract}

The incidence and numbers of treponemes in the human gingival flora become greater as gingivitis becomes more severe (27). The number of treponemes increases to approximately more than $50 \%$ of all bacterial morphotypes in subgingival samples from periodontitis patients $(10,12,13,27)$. Some oral treponemal species have been associated with soft-tissue damage due to proteolytic enzymes or with inflammatory reactions due to antibodies against their specific antigens, and eventually this leads to periodontal tissue destruction in certain types of periodontal disease $(12,18,21,36)$. Simonson et al., for instance, have reported that Treponema denticola is linked to the severity of periodontal disease (25). All of the human oral spirochetes mentioned above belong to the genus Treponema in the family Spirochaetaceae; these bacteria characteristically are tightly coiled organisms that consist of a protoplasmic cylinder (length, approximately 6 to $20 \mu \mathrm{m}$; width, 0.1 to $0.5 \mu \mathrm{m}$ ) covered by an envelope (an outer sheath) and periplasmic flagella (axial flagella) which originate subterminally at the ends of the protoplasmic cylinder (26). Choi et al. used a 16S rRNA gene cloning technique to document the qualitative nature of human oral spirochetes and demonstrated that there is great genetic diversity in oral spirochetes, even in a single periodontitis patient (2). Human oral spirochetes, however, have been conventionally grouped into the following three morphotypes: (i) small spirochetes, including $T$. denticola, Treponema socranskii, and Treponema pectinovorum; (ii) medium-sized spirochetes, such as Treponema vincentii; and (iii) large spirochetes which have not been isolated in pure culture $(3,11)$.

$T$. denticola, $T$. socranskii, $T$. pectinovorum, T. vincentii, Treponema scoliodontum, Treponema macrodentium, and Treponema orale have been described as human oral Treponema species, although the last two species have no standing in nomenclature at this time (26-28). $T$. denticola and $T$. socranskii also have been reported to be the most common species in human oral samples (27). Riviere et al. investigated the subgingival distribution of these two spirochetes and a pathogen-

* Corresponding author. Mailing address: Department of Oral Microbiology, Asahi University School of Dentistry, Hozumi, Gifu-Ken, 501-02 Japan. Phone and fax: (81) 058-329-1423. E-mail: toshiut @hatelecom.or.jp. related spirochete with different periodontal status and reported that human oral spirochetes were not uniformly distributed within the dentition or around individual teeth (23).

We isolated Treponema sp. strain $\mathrm{G} 7201^{\mathrm{T}}$ ( $\mathrm{T}=$ type strain), which could not be classified in any previously described species. We examined the phenotypic, serologic, and genetic characteristics of this organism and compared the results with data for reference species.

In this paper we describe the characteristics of this Treponema strain and propose a new species, Treponema medium, for it on the basis of morphological, biochemical, and immunological characteristics, DNA-DNA hybridization data, and $16 \mathrm{~S}$ rRNA sequence data.

\section{MATERIALS AND METHODS}

Bacterial strains and culture conditions. A host-associated spirochete, strain $\mathrm{G} 7201^{\mathrm{T}}$, was isolated from a subgingival plaque sample from a 52 -year-old male patient with adult periodontitis by a well-plate method as described by Rosebury and Foley (24). Briefly, subgingival plaque samples were suspended in sterile saline, and the resulting suspension $(0.2 \mathrm{ml})$ was subcutaneously injected into guinea pigs (weight, approximately $250 \mathrm{~g}$ ). Pus was aseptically removed from swollen lesions on the guinea pigs and then placed in agar wells, each approximately $2 \mathrm{~mm}$ wide and $1 \mathrm{~cm}$ deep, on $12.5 \%$ inactivated horse serum-containing sterility test medium plates (BBL Microbiology Systems, Cockeysville, Md.) in a candle jar. White haze growing out from each well into the agar and away from bacterial contaminants was observed after 10 days of anaerobic incubation at $37^{\circ} \mathrm{C}$. Agar plugs at the leading edge of the haze were cut with a sterile glass pipette and were transferred into agar wells in fresh agar plates. In order to obtain a pure culture, the procedure was repeated more than 10 times, and spirochetal colonies were picked from solid sterility test medium supplemented with horse serum (35). Later, TYGVS medium was used as the routine culture medium and an anaerobic chamber $\left(85 \% \mathrm{~N}_{2}, 10 \% \mathrm{H}_{2}, 5 \% \mathrm{CO}_{2}\right)$ was used for anaerobic conditions $(34,36)$.

$T$ denticola ATCC 33520 and ATCC 35405, T. socranskii subsp. buccale ATCC $35534, T$. socranskii subsp. socranskii ATCC 35536, T. vincentii ATCC 35580 , Treponema phagedenis biotype Reiter, and an avirulent variant, Treponema pallidum ATCC 27087, were used as reference organisms in this study. T. socranskii was grown anaerobically in modified NOS medium (ATCC medium 1494). The other microorganisms were grown in TYGVS medium at $37^{\circ} \mathrm{C}$ for 4 to 7 days (29). Each strain was harvested by centrifugation and washed twice in $0.01 \mathrm{M}$ phosphate-buffered saline ( $\mathrm{pH} 7.2$ ).

Electron microscopy. Fresh microorganisms from a 3-day-old culture of strain $\mathrm{G} 7201^{\mathrm{T}}$ were harvested by centrifugation at $5,000 \times \mathrm{g}$ for $10 \mathrm{~min}$ and were gently washed three times in phosphate-buffered saline and once in distilled water. The resulting bacterial suspension was placed on collodion membrane-coated copper grids. The cells were negatively stained with a $1 \%$ phosphotungstic acid solution (pH 7.0) and observed with an electron microscope (model JEM 1200EX; JEOL, Tokyo, Japan). For scanning electron microscopy, the washed bacterial cells were 
also fixed for $30 \mathrm{~min}$ at room temperature in a $2.5 \%$ glutaraldehyde solution and for $30 \mathrm{~min}$ in a $1 \%$ osmium tetroxide solution; both of these solutions were buffered at $\mathrm{pH} 7.2$ with $0.1 \mathrm{M}$ cacodylate buffer. The fixed cells were then washed three times with distilled water. Aliquots were placed on the hydrophilic surfaces of GelBond PAG film disks (diameter, $6 \mathrm{~mm}$; FMC BioProducts, Rockland, Maine), which were dried in air, mounted on specimen holders, and observed with a scanning electron microscope (model JSM-356C; JEOL).

Biochemical characterization. The routine tests used for strain $G 7201^{\mathrm{T}}$ included tests for acid production from sugars; production of indole; catalase; gas and ammonia; hydrolysis of gelatin, esculin, and hippurate; and nitrate reduction. Sterility test medium and glucose-free thioglycolate medium (BBL) which had been supplemented with $15 \%$ inactivated horse serum were used as the basa media. The procedures used to determine biochemical characteristics were similar to the procedures described by Sutter et al. (32). Tests that produced questionable results were repeated.

Production of volatile fatty acids. The short-chain fatty acids in a 7-day-old TYGVS culture were converted to methyl esters and studied by a conventional procedure, using capillary gas chromatography (model GC- 8 gas-liquid chromatograph; Shimadzu, Tokyo, Japan), a glass Chromosorb W80/100 column (diameter, $3 \mathrm{~mm}$; length, $2 \mathrm{~m}$; Shinwa Chemical Industries, Kyoto, Japan), and a flame ionization detector under the following operational conditions: column temperature, $160^{\circ} \mathrm{C}$ (isothermal); injection and detection temperature, $210^{\circ} \mathrm{C}$ and nitrogen gas flow rate, $50 \mathrm{ml} / \mathrm{min}$.

SDS-PAGE and Western immunoblotting analysis. Sodium dodecyl sulfate (SDS)-polyacrylamide gel electrophoresis (PAGE) was performed by the method of Laemmli (9) with a MicroSlab model KS-8010 gel electrophoresis system (Marysol, Tokyo, Japan). Whole bacterial cells of each strain were heated in solubilizing buffer $(0.125 \mathrm{~N}$ Tris buffer [pH 6.8] containing $4 \%$ [wt/vol] SDS $20 \%[\mathrm{vol} / \mathrm{vol}]$ glycerol, and $5 \%$ [vol $/ \mathrm{vol}] 2$-mercaptoethanol) for $10 \mathrm{~min}$ at $100^{\circ} \mathrm{C}$ After centrifugation at $10,000 \times g$ for $15 \mathrm{~min}$, the protein concentration of the supernatant was determined with a protein assay kit (Bio-Rad Laboratories, Richmond, Calif.). Supernatant $(10 \mu \mathrm{g})$ from each bacterial strain was applied to an SDS-10\% polyacrylamide gel. Electrophoresis was performed at a constant current of $20 \mathrm{~mA}$ at room temperature. After electrophoresis, the gel was stained with Coomassie brilliant blue R-250 or used for Western transfer. Western transfer of the antigens from the gel to a nitrocellulose membrane was performed as described previously $(19,34)$. An immunoblotting analysis was carried out by using goat anti-rabbit immunoglobulin $\mathrm{G}$ conjugated with peroxidase as the second antibody as described previously (19). It has been reported that a polypeptide is a main antigen of strain $\mathrm{G} 7201^{\mathrm{T}}(17)$. Therefore, a polyclonal rabbit antiserum against the $44-\mathrm{kDa}$ polypeptide was used in the immunoblotting analysis as the first antibody.

DNA isolation. Bacterial cells (wet weight, $1 \mathrm{~g}$ ) were resuspended in $5 \mathrm{ml}$ of saline-EDTA buffer ( $0.15 \mathrm{M} \mathrm{NaCl}, 0.1 \mathrm{M}$ EDTA; $\mathrm{pH} 8.0)$. After $15 \mathrm{ml}$ of $0.1 \mathrm{M}$ Tris buffer ( $\mathrm{pH} 9.0$ ) containing 1\% (wt/vol) SDS was added, the preparation was incubated at $60^{\circ} \mathrm{C}$ until the solution became clear. DNA was isolated from the resulting cell lysate by the method of Marmur (14), with slight modifications (20). The DNA concentrations of the preparations were determined spectrophotometrically by determining the $A_{260}$-to- $A_{280}$ ratio.

DNA base composition. The guanine-plus-cytosine $(\mathrm{G}+\mathrm{C})$ content of DNA was estimated by high-performance liquid chromatography (HPLC) (8). Each DNA preparation was dissolved in distilled water to a concentration of $1 \mathrm{mg} / \mathrm{ml}$, and then the solution was heated at $100^{\circ} \mathrm{C}$ for $5 \mathrm{~min}$. After rapid cooling in an ice bath, $10 \mu \mathrm{l}$ of the resulting denatured DNA solution was reacted with $10 \mu \mathrm{l}$ of a nuclease P1 (Yamasa Shoyu Co., Chiba, Japan) solution $(2 \mathrm{U} / \mathrm{ml}$ of $40 \mathrm{mM}$

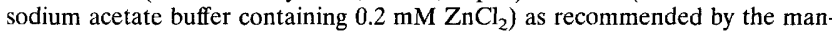
ufacturer. The hydrolysate and a standard solution containing equal concentrations of four deoxyribonucleotide monophosphates (dAMP, dCMP, dGMP, and dTMP) were subjected separately to HPLC by using a Hitachi model L-6200 apparatus and a type $3013-\mathrm{N}$ column ( 4 by $150 \mathrm{~mm}$ ). The column was eluted with a mobile phase containing $30 \mathrm{mM} \mathrm{KCl}, 10 \mathrm{mM} \mathrm{KH}_{2} \mathrm{PO}_{4}$, and $10 \% \mathrm{CH}_{3} \mathrm{CN}(\mathrm{pH}$ 3.5). The deoxyribonucleotide monophosphates were detected with a Hitachi model L-4200 apparatus at $267 \mathrm{~nm}$.

DNA-DNA hybridization. The extent of DNA-DNA reassociation was determined by the membrane filter method described by Meyer and Schleifer (15), with a slight modification (20). Triplicate tests were run for each assay, and the results were normalized to $100 \%$ for the homologous DNA-DNA hybridization experiment.

Sequencing of the 16S rRNA gene. A nucleotide primer set (5'-GCT GGC AGT GCG TCT TAA GCA TGC-3', located at positions 35 to 58 [Escherichia coli numbering], and 5'-GTG ACG GGC GGT GTG TAC AAG GCC C-3', located at positions 1408 to 1384) was synthesized and used for PCR amplification. PCR amplification was performed as described previously (4). The DNA fragment obtained by PCR amplification was sequenced by using a Thermo Sequenase labeled primer cycle sequencing kit (Amersham Japan, Osaka, Japan) and a series of custom-synthesized primers (5). Phylogenetic analysis was performed by using the DNASTAR program (DNASTAR, Inc., Madison, Wis.) and nucleotide sequence pair similarity values for the sequences were calculated by using the CLUSTAL V method (6). Confidence intervals were assessed by performing a CLUSTAL V bootstrap analysis.

Nucleotide sequence accession numbers. The $16 \mathrm{~S}$ rRNA gene sequences of Treponema strains determined in this study have been assigned DDBJ, EMBL, and GenBank accession numbers D85437 (strain G7201 ${ }^{\mathrm{T}}$ ) and D85438 (T. denticola 33520). Previously published sequences were also used in this study; these sequences included the sequences of Spirochaeta zuelzerae (accession number M34265), T. pallidum (M34266), T. phagedenis (M57739), Treponema saccharophilum (M71238), Treponema succinifaciens (M577381), Treponema rumen CA (M59294), Treponema bryantii (M57737), Treponema pectinovorum (M71237), Borrelia burgdorferi (M88329), and Leptospira interrogans (X17547) (22).

\section{RESULTS}

Morphological characteristics. The optimum temperature for growth of $T$. medium $\mathrm{G} 7201^{\mathrm{T}}$ was $37^{\circ} \mathrm{C}$. The cells were between 5 and $16 \mu \mathrm{m}$ long and about 0.2 to $0.3 \mu \mathrm{m}$ wide under the culture conditions employed. Each spirochetal cell had relatively blunt ends and five to seven periplasmic flagella that originated subterminally at the ends of the protoplasmic cylinder (Fig. 1). In addition, electron microscopic observation of negatively stained cells revealed that this microorganism had intracytoplasmic tubules (formerly designated fine fibrils) within the cytoplasmic cylinder (Fig. 1). We observed these tubules, each of which was approximately $10 \mathrm{~nm}$ in diameter, just under the two electron-dense layers of the protoplasmic cylinder (33). Possession of cytoplasmic tubules by spirochetes is one of the important criteria for classification in the genus Treponema $(7,16)$.

Biochemical characteristics. T. medium $\mathrm{G} 7201^{\mathrm{T}}$ fermented glucose, fructose, maltose, mannose, galactose, sucrose, ribose, trehalose, inulin, salicin, and raffinose, but did not ferment mannitol, arabinose, sorbitol, adonitol, xylose, or lactose. This organism also produced ammonia and hydrogen sulfate, but not indole, and hydrolyzed esculin and hippuric acid, but not gelatin. This strain was nitrate reduction negative. The volatile fatty acids produced in conventional TYGVS medium containing $0.1 \%$ glucose by strain $\mathrm{G} 7201^{\mathrm{T}}$ were detected by gas-liquid chromatography. This strain produced predominantly acetic acid and $n$-butyric acid, as well as traces of $n$-valeric acid. The phenotypic characteristics of $T$. medium $G 7201^{\mathrm{T}}$ are shown in Table 1.

SDS-PAGE protein profiles and Western immunoblotting reactions. The protein profile of $T$. medium had major protein bands in the region between about 80 and $30 \mathrm{kDa}$ and seemed to be different from the protein profiles of previously described Treponema species, including $T$. denticola, $T$. vincentii, $T$. socranskii, T. phagedenis, and T. pallidum (Fig. 2). Western immunoblotting assays in which anti-rabbit immunoglobulin $\mathrm{G}$ was used as a conjugate revealed that anti-44-kDa protein serum, which was an antiserum against a major $44-\mathrm{kDa}$ antigen of $T$. medium $\mathrm{G} 7201^{\mathrm{T}}$, did not react with the antigens from $T$. denticola, $T$. vincentii, $T$. socranskii, $T$. phagedenis, and $T$. pallidum (data not shown). These results demonstrated that $T$. medium could be distinguished from the reference species by its protein components, including the structural proteins of whole bacterial cells, and by its immunological reactions.

$\mathbf{G}+\mathbf{C}$ contents. As reported previously (22), the $\mathrm{G}+\mathrm{C}$ contents of Treponema species range widely, from 36 to $54 \mathrm{~mol} \%$, as determined by the thermal melting method. The $\mathrm{G}+\mathrm{C}$ content of $T$. medium $\mathrm{G} 7201^{\mathrm{T}}$ was $51 \mathrm{~mol} \%$, as determined by HPLC in the present study. This value is almost the same as the $\mathrm{G}+\mathrm{C}$ content of $T$. socranskii, which has three subspecies (50 to $52 \mathrm{~mol} \%$ ) (27).

DNA-DNA hybridization. The DNA of $T$. medium exhibited very low levels of reassociation with the DNAs of the other Treponema species examined in the present study, as shown in Table 2. The data in Table 2 revealed that $T$. medium was completely distinct from the other Treponema species. The quantitative DNA-DNA hybridization studies performed by the filter membrane method also showed that the labeled DNA 


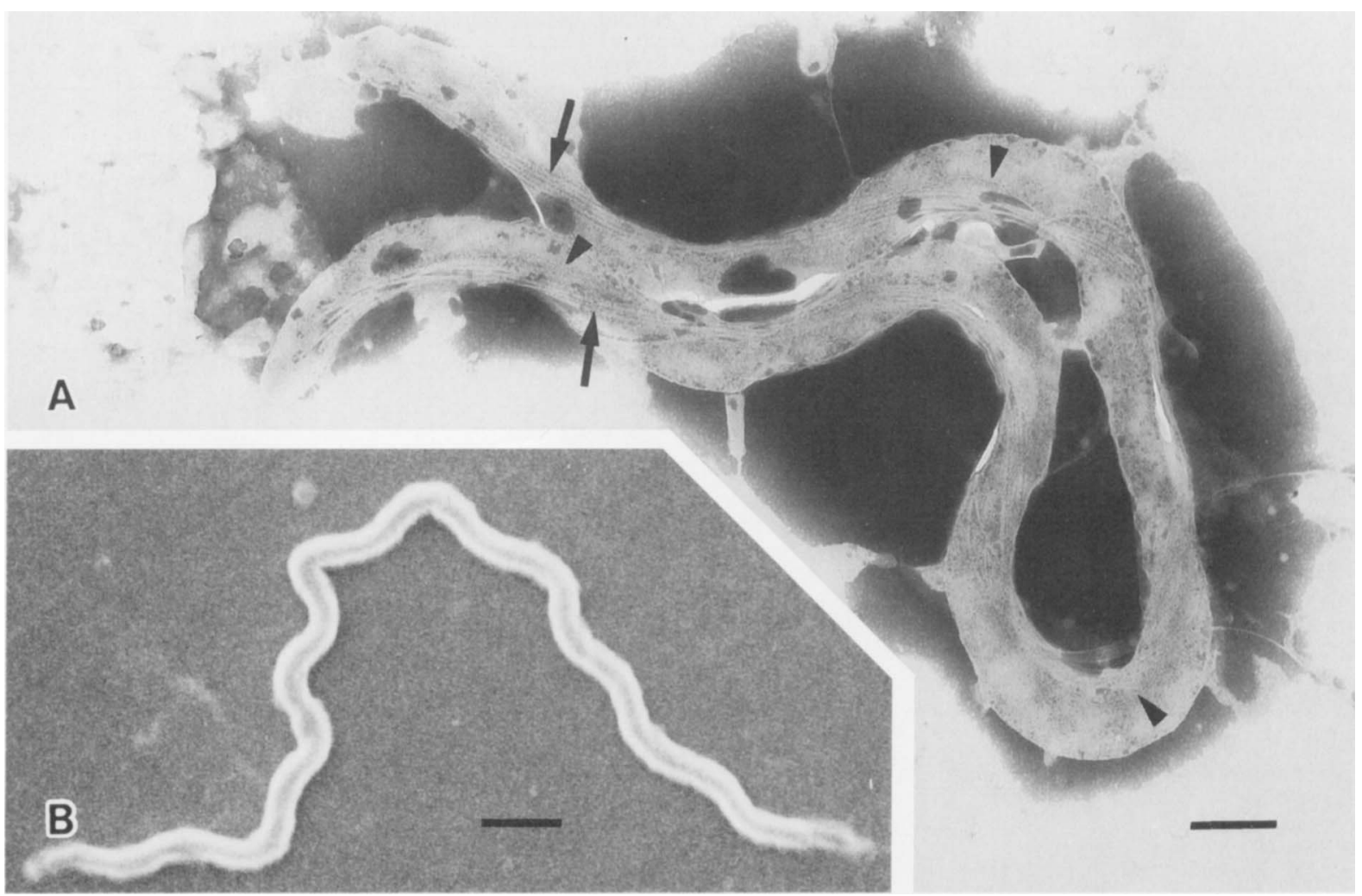

FIG. 1. Electron micrographs showing typical morphology of strain G7201 ${ }^{\mathrm{T}}$. (A) Negatively stained cell. Periplasmic flagella (arrows) originating subterminally at the ends of the cell and intracytoplasmic tubules (arrowheads) in the cytoplasmic cylinder are visible, but the outer envelope was lost during sample preparation. Bar $=$ $250 \mathrm{~nm}$. (B) Scanning electron micrograph. Bar $=500 \mathrm{~nm}$.

probe from T. denticola ATCC 33520 was reasonably homologous (level of homology, 95\%) with DNA from T. denticola ATCC 35405, which was consistent with the results of Chan et al. (1). This observation supports the validity of the data obtained for the species studied.

Sequence and phylogenetic analysis. We cloned the $16 \mathrm{~S}$ rRNA genes of $T$. denticola ATCC 33520 and $T$. medium $\mathrm{G} 7201^{\mathrm{T}}$, and the nucleotide sequences (length, 1,381 bases) were determined in order to quantitatively assess the phylogenetic relationships to strains belonging to other treponemal species, including Treponema bryantii, T. pallidum, T. pectinovorum, $T$. phagedenis, $T$. rumen, $T$. succinifaciens, $T$. saccharophilum, and Spirochaeta zuelzerae, and two other pathogenic spirochetes, the agent of Lyme disease (Borrelia burgdorferi) and Leptospira interrogans (which is associated with Weil's disease). The $T$. medium $16 \mathrm{~S}$ rRNA gene sequence (length without PCR primer sequences, 1,381 bases) was aligned and compared with the sequences of other treponemes by using the DNASTAR program.

The nucleotide sequence pair similarity values for the sequences are shown in Table 3 , and a neighbor-joining phylogenetic tree constructed on the basis of the data in the sequence similarity matrix is shown in Fig. 3. The phylogenetic analysis placed strain $\mathrm{G} 7201^{\mathrm{T}}$ in a coherent cluster of Treponema species, and T. medium $\mathrm{G} 7201^{\mathrm{T}}$, T. phagedenis, T. denticola, and $T$. pallidum belonged to a group different from the human oral organism $T$. pectinovorum. The tree in Fig. 3 clearly shows that strain $\mathrm{G} 7201^{\mathrm{T}}$ is not closely related to the other organisms in the cluster and that this strain seems to have diverged at the species level.

\section{DISCUSSION}

The differential characteristics of human oral treponemes, including $T$. medium $\mathrm{G} 7201^{\mathrm{T}}$, are compared in Table 1 . When T. medium is compared morphologically with previously described human oral spirochetes, it can be distinguished from $T$. denticola, $T$. pectinovorum, $T$. socranskii, $T$. macrodentium, and $T$. orale by the number of periplasmic flagella, although the cell lengths and cell widths of these organisms are similar. The medium-sized human oral treponeme $T$. vincentii has four to six periplasmic flagella but is not able to ferment carbohydrates (26), suggesting that the saccharolytic organism $T$. medium $\mathrm{G} 7201^{\mathrm{T}}$, which has five to seven periplasmic flagella, can be distinguished from $T$. vincentii. The $\mathrm{G}+\mathrm{C}$ content and SDSPAGE protein profile data also support this distinction. In addition, $T$. medium exhibits only $28 \%$ DNA homology with $T$. vincentii, indicating that $T$. medium is different from $T$. vincentii.

Although the number of periplasmic flagella and the $\mathrm{G}+\mathrm{C}$ content of $T$. scoliodontum have not been reported, this small asaccharolytic species is different from saccharolytic strain $\mathrm{G} 7201^{\mathrm{T}}$. T. phagedenis, Treponema refringens, and Treponema minutum are found in human genitalia. T. phagedenis has three to eight periplasmic flagella and a $\mathrm{G}+\mathrm{C}$ content of 38 to 39 mol\%, T. refringens has two to four periplasmic flagella and a $\mathrm{G}+\mathrm{C}$ content of 39 to $43 \mathrm{~mol} \%$, and $T$. minutum has two or three periplasmic flagella and a $\mathrm{G}+\mathrm{C}$ content of $37 \mathrm{~mol} \%$ (26), suggesting that strain $\mathrm{G} 7201^{\mathrm{T}}$ (with five to seven periplasmic flagella and a $\mathrm{G}+\mathrm{C}$ content of $51 \mathrm{~mol} \%$ ) can be readily distinguished from these human genitalia-inhabiting species. Phy- 
TABLE 1. Differential characteristics of human oral Treponema species $^{a}$

\begin{tabular}{|c|c|c|c|c|c|c|c|c|}
\hline Characteristic & T. medium & T. denticola & T. pectinovonum & T. scoliodontum & T. socranskii & T. vincentii & T. macrodentium & T. orale \\
\hline Cell length $(\mu \mathrm{m})$ & $6-15$ & $6-16$ & $7-15$ & $6-16$ & $6-15$ & $5-16$ & $5-16$ & $6-16$ \\
\hline Cell width $(\mu \mathrm{m})$ & $0.20-0.30$ & $0.15-0.20$ & $0.28-0.30$ & $0.15-0.20$ & $0.16-0.18$ & $0.20-0.25$ & $0.10-0.25$ & $0.15-0.25$ \\
\hline No. of periplasmic flagella & $5-7$ & $2-3$ & 2 & $\mathrm{NR}^{b}$ & 1 & $4-6$ & 1 & 1 \\
\hline \multicolumn{9}{|l|}{ Fermentation of: } \\
\hline Glucose & + & - & - & - & + & - & + & - \\
\hline Fructose & + & - & - & - & + & - & + & - \\
\hline Lactose & - & - & - & - & - & - & - & - \\
\hline Maltose & + & - & - & - & + & - & + & - \\
\hline Mannitol & - & - & - & - & NR & - & - & - \\
\hline Mannose & + & -- & - & - & + & - & + & - \\
\hline Galactose & + & - & - & - & + & - & + & - \\
\hline Starch & $\mathrm{ND}^{c}$ & - & - & - & NR & - & + & - \\
\hline Sucrose & + & - & - & - & + & - & + & - \\
\hline Ribose & + & - & - & - & + & - & + & - \\
\hline Xylose & - & - & - & - & + & - & + & - \\
\hline \multicolumn{9}{|l|}{ Hydrolysis of: } \\
\hline Esculin & + & + & - & - & - & $-^{d}$ & NR & + \\
\hline Gelatin & - & + & - & - & $-^{d}$ & - & - & + \\
\hline \multicolumn{9}{|l|}{ Production of: } \\
\hline Ammonia & + & + & + & - & + & + & - & - \\
\hline Indole & - & $-^{d}$ & - & - & - & + & - & - \\
\hline Hydrogen sulfate & + & + & - & + & + & + & + & + \\
\hline Fatty acids produced ${ }^{e}$ & $\mathrm{~A}, \mathrm{~B}, \mathrm{v}$ & $\mathrm{A}, \mathrm{l}, \mathrm{s}, \mathrm{p}, \mathrm{f}$ & $\mathrm{A}, \mathrm{F}, \mathrm{p}, \mathrm{l}$ & $\mathrm{A}, \mathrm{f}, \mathrm{p}, \mathrm{l}, \mathrm{s}$ & $\mathrm{A}, \mathrm{L}, \mathrm{S}, \mathrm{f}$ & $\mathrm{A}, \mathrm{B}, 1, \mathrm{~s}$ & $\mathrm{~A}, \mathrm{~F}, \mathrm{~L}$ & $\mathrm{~A}, \mathrm{p}$ \\
\hline $\mathrm{G}+\mathrm{C}$ content $(\mathrm{mol} \%)$ & 51 & $37-38$ & 39 & NR & $50-52$ & 44 & 39 & 37 \\
\hline
\end{tabular}

${ }^{a}$ Data for all species except T. medium are from references $15,24,25$, and 27 .

${ }^{b} \mathrm{NR}$, not reported.

${ }^{c} \mathrm{ND}$, not determined.

${ }^{d}$ Some strains were positive, and some were negative.

e A, acetic acid; B, $n$-butyric acid; $\mathrm{F}$ and $\mathrm{f}$, fumaric acid; $\mathrm{L}$ and $\mathrm{l}$, lactic acid; $\mathrm{S}$ and s, succinic acid; $\mathrm{p}$, propionic acid; $\mathrm{v}, n$-valeric acid. Uppercase letters indicate major fatty acids, and lowercase letters indicate minor fatty acids.

logenetic data distinguish $T$. medium from $T$. phagedenis as well as $T$. denticola (Fig. 3). T. medium also seems to be distinguished from the culturable and fermentative organisms $T$. bryantii, T. succinifaciens, and T. saccharophilum on the basis of

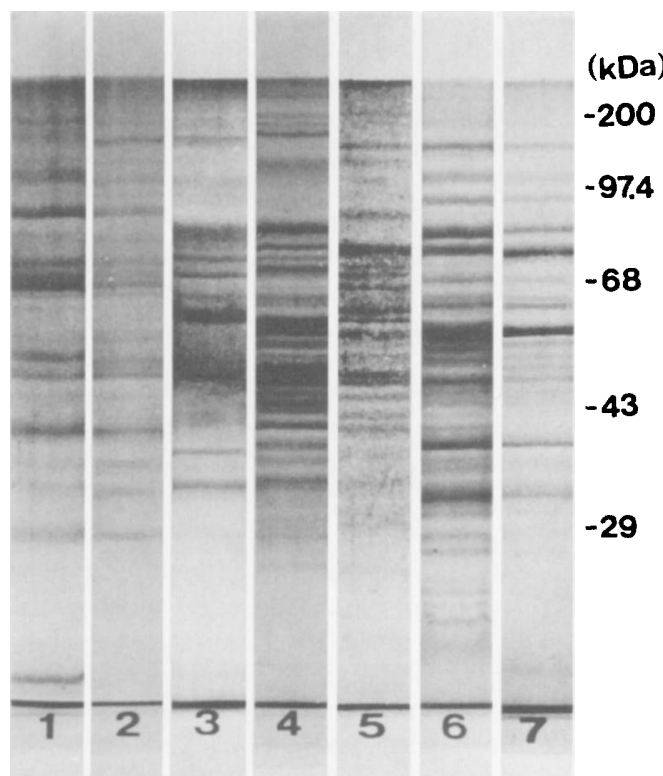

FIG. 2. Coomassie brilliant blue-stained polypeptide patterns of whole cells of seven treponemes on an SDS-polyacrylamide gel. Lane 1, T. pallidum ATCC 27087; lane 2, T. phagedenis biotype Reiter; lane 3, strain G7201 ${ }^{\mathrm{T}}$; lane 4, T. vincentii ATCC 35580 ; lane $5, T$. socranskii subsp. buccale ATCC 35534; lane 6 , $T$. denticola ATCC 35405; lane 7, T. denticola ATCC 33520. The positions of molecular weight standards are shown on the right. the lower $\mathrm{G}+\mathrm{C}$ contents of the latter organisms (approximately $36 \mathrm{~mol} \%$ ) and the fact that the latter organisms have one or two periplasmic flagella (26). Treponema innocens and Treponema hyodysenteriae, both of which have relatively short cells and $\mathrm{G}+\mathrm{C}$ contents of 25.7 to $25.9 \mathrm{~mol} \%$ and were initially isolated from swine intestinal materials, have been reclassified in the genus Serpulina $(30,31)$. T. denticola $(\mathrm{G}+\mathrm{C}$ content, 37 to $38 \mathrm{~mol} \%$ ) and $T$. pallidum ( $\mathrm{G}+\mathrm{C}$ content, 52 to $53.7 \mathrm{~mol} \%$ ), however, are quite different (22). In addition, $T$. socranskii, a saccharolytic hydrogen sulfate producer with a $\mathrm{G}+\mathrm{C}$ content of 50 to $52 \mathrm{~mol} \%$, differs from $T$. pectinovorum, an asaccharolytic organism that does not produce hydrogen sulfate and has a $\mathrm{G}+\mathrm{C}$ content of 39 mol\% (Table 1 ).

Comparative analysis of the $16 \mathrm{~S}$ rRNA sequences of individual bacteria has been widely used to reveal phylogenetic relationships among spirochetes. $T$. denticola, $T$. phagedenis, and $T$. pallidum form a phylogenetic cluster, and $T$. socranskii and $T$. pectinovorum are closely related in another cluster (22). We determined the $16 \mathrm{~S}$ rRNA gene sequence of strain $G 7201^{\mathrm{T}}$ and aligned and compared this sequence with the sequences of

TABLE 2. Levels of DNA relatedness between strain G7201 ${ }^{\mathrm{T}}$ and strains of other Treponema species

\begin{tabular}{|c|c|}
\hline Source of unlabeled DNA & $\begin{array}{l}\% \text { Homology with labeled } \\
\text { DNA from strain G7201T }\end{array}$ \\
\hline \multicolumn{2}{|c|}{ 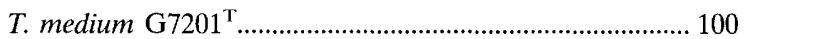 } \\
\hline T. denticola ATCC 33520. & ..... \\
\hline T. denticola ATCC $35405 \ldots .$. & ..................... \\
\hline 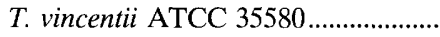 & $\ldots \ldots \ldots \ldots \ldots . . . . . . . . .28$ \\
\hline T. socranskii subsp. socranskii ATCC & .................... 30 \\
\hline T. phagedenis biotype Reiter ......... & ...................... \\
\hline T. pallidum ATCC $27087 \ldots \ldots \ldots \ldots . . . .$. & ................... \\
\hline
\end{tabular}


TABLE 3. 16S rRNA sequence similarity matrix for members of the genus Treponema and related organisms

\begin{tabular}{|c|c|c|c|c|c|c|c|c|c|c|c|c|c|}
\hline \multirow[b]{2}{*}{ Organism } & \multicolumn{13}{|c|}{$\% 16 \mathrm{~S}$ rRNA similarity } \\
\hline & 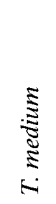 & 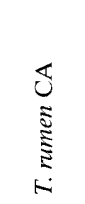 & 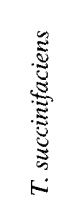 & 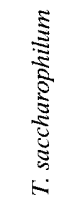 & 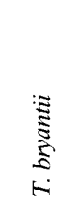 & 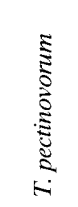 & 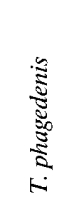 & 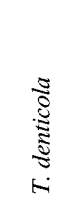 & 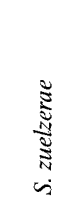 & 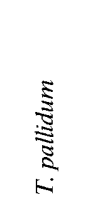 & 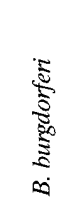 & 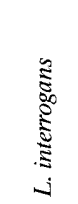 & $\begin{array}{l}\dot{\tilde{\Xi}} \\
\dot{u}\end{array}$ \\
\hline T. medium & 100 & 76.0 & 72.7 & 78.4 & 79.2 & 78.5 & 88.1 & 88.0 & 84.2 & 84.5 & 73.5 & 66.8 & 67.2 \\
\hline T. rumen $\mathrm{CA}$ & & 100 & 80.1 & 81.7 & 80.0 & 78.5 & 76.4 & 78.1 & 75.8 & 77.9 & 69.6 & 66.5 & 65.3 \\
\hline T. succinifaciens & & & 100 & 75.1 & 78.4 & 75.3 & 73.6 & 74.8 & 71.9 & 74.9 & 64.9 & 62.5 & 61.4 \\
\hline T. saccharophilum & & & & 100 & 77.6 & 80.5 & 78.1 & 79.4 & 76.3 & 77.4 & 69.2 & 63.1 & 64.5 \\
\hline T. bryantii & & & & & 100 & 82.4 & 78.9 & 79.5 & 77.5 & 77.8 & 71.8 & 63.6 & 65.2 \\
\hline T. pectinovorum & & & & & & 100 & 77.9 & 79.2 & 76.6 & 76.1 & 69.0 & 61.3 & 61.8 \\
\hline T. phagedenis & & & & & & & 100 & 90.1 & 84.2 & 87.1 & 72.2 & 64.9 & 65.1 \\
\hline T. denticola & & & & & & & & 100 & 84.6 & 86.6 & 73.7 & 68.8 & 65.4 \\
\hline S. zuelzerae & & & & & & & & & 100 & 80.9 & 71.0 & 64.3 & 62.7 \\
\hline T. pallidun & & & & & & & & & & 100 & 74.4 & 67.1 & 65.8 \\
\hline B. burgdorferi & & & & & & & & & & & 100 & 56.9 & 66.5 \\
\hline L. interrogans & & & & & & & & & & & & 100 & 68.2 \\
\hline E. coli & & & & & & & & & & & & & 100 \\
\hline
\end{tabular}

other spirochetes by using the DNASTAR program. A neighbor-joining phylogenetic tree constructed on the basis of the sequence similarity matrix data is shown in Fig. 3. According to this tree, Treponema strains could be divided into two major clusters. Strain $\mathrm{G} 7201^{\mathrm{T}}$ belonged to a cluster that included T. phagedenis, T. denticola, S. zuelzerae, and T. pallidum. Our phylogenetic analysis based on $16 \mathrm{~S}$ rRNA gene sequences revealed that strain $G 7201^{\mathrm{T}}$ diverged at the species level, which is consistent with the creation of a new species.

It should be noted that the levels of reassociation between the DNA of $T$. medium and the DNAs of $T$. denticola and $T$. pallidum, which is the type species of the genus Treponema, were less than $10 \%$ (Table 2). Our DNA-DNA homology data showed that strain $\mathrm{G} 7201^{\mathrm{T}}$ was similar in distance from $T$. socranskii and $T$. vincentii (levels of homology, approximately $30 \%$ ). This finding strongly supports the proposal that T. me-

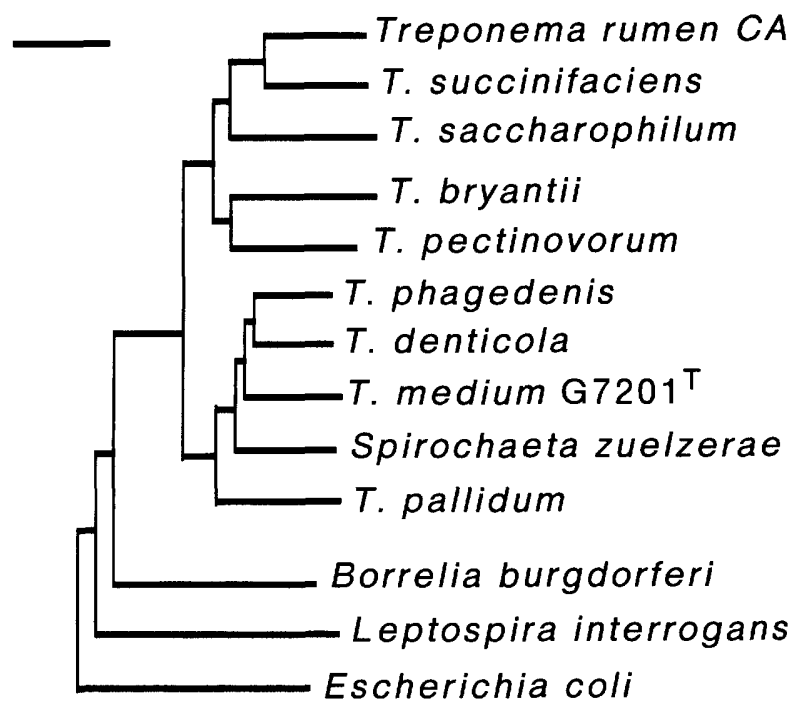

FIG. 3. Phylogenetic tree for spirochetes. The phylogenetic tree was constructed as described in the text by using 16S rRNA gene sequences. Bar $=5 \%$ difference between sequences, as determined by measuring the lengths of the horizontal lines connecting specics. The 16S rRNA gene sequence of Escherichia coli served as an outgroup. dium should be considered a new species which is isolated from human dental cavities.

At present, we have no information on the distribution or incidence of this species in human mouths. An immunological survey is in progress; in this survey, subgingival plaque samples from clinically classified patients and polyclonal antibodies against species-specific surface antigens from this microorganism are being used. The pathogenicity of oral spirochete strain $\mathrm{G} 7201^{\mathrm{T}}$ is not known at present.

On the basis of morphological and biochemical characteristics, the results of SDS-PAGE and a Western immunoblotting analysis, DNA-DNA hybridization data, and 16S rRNA sequence data, we propose a new species, T. medium, for strain $\mathrm{G} 7201^{\mathrm{T}}$. The taxonomic description below summarizes the properties of this species.

Description of Treponema medium sp. nov. Treponema medium (me'di.um. L. adj. medium, medium, referring to the cell size) is a gram-negative, anaerobic, motile, helically coiled, medium-sized treponeme. The cells are 5 to $16 \mu \mathrm{m}$ long and 0.2 to $0.3 \mu \mathrm{m}$ wide. They have cytoplasmic tubules and five to seven periplasmic flagella (axial flagella) that originate subterminally at each end. The cells in broth cultures exhibit rotational and translational movement. The optimum growth temperature is $37^{\circ} \mathrm{C}$, and colonies on agar plates are white and translucent. T. medium ferments glucose, fructose, maltose, mannose, galactose, sucrose, ribose, trehalose, inulin, salicin, and raffinose. This organism also produces ammonia and hydrogen sulfate and hydrolyzes esculin and hippuric acid. The major acid products of strain $\mathrm{G} 7201^{\mathrm{T}}$ grown in TYGVS medium containing $0.1 \%$ glucose are acetic acid and $n$-butyric acid. A trace of $n$-valeric acid is also found. Isolated from subgingival plaque of patients with adult periodontitis. The $\mathrm{G}+\mathrm{C}$ content is $51 \mathrm{~mol} \%$. The type strain of $T$. medium is strain G7201.

Phenotypic characteristics, DNA-DNA hybridization data, $\mathrm{G}+\mathrm{C}$ content data, and $16 \mathrm{~S}$ rRNA gene sequence data indicate that human oral spirochete strain $\mathrm{G} 7201^{\mathrm{T}}$ should be identified as member of a novel species, T. medium.

\section{ACKNOWLEDGMENTS}

We appreciate the help of $\mathrm{H}$. Nitta and Mingyu $\mathrm{Li}$, Department of Oral Microbiology, School of Dentistry, Asahi University, Gifu, Japan, for bacterial cultures and electron microscopy.

This study was supported in part by grants-in-aid for scientific re- 
search 04304044, 05807169, 06044082, 07457427, and 07807166 from the Ministry of Education, Science and Culture of Japan, by a grant from Yakult Company, Ltd., Tokai Branch, Nagoya, Japan, by a grant from the Japan-China Medical Association (1995), Tokyo, Japan, and by a Miyata research grant (1995,A) from Asahi University.

\section{REFERENCES}

1. Chan, E. C. S., R. Siboo, T. Keng, N. Psarra, R. Hurley, S. L. Cheng, and I. Iugovae. 1993. Treponema denticola (ex Brumpt 1925) sp. nov., nov. rev., and identification of new spirochete isolates from periodontal pockets. Int. J. Syst. Bacteriol. 43:196-203.

2. Choi, B. K., B. J. Paster, F. E. Dewhirst, and U. B. Göbel. 1994. Diversity of cultivable and uncultivable oral spirochetes from a patient with severe destructive periodontitis. Infect. Immun. 62:1889-1895.

3. Dahle, U. R., L. Tronstad, and I. Olsen. 1993. Observation of an unusually large spirochete in endodontic infection. Oral Microbiol. Immunol. 8:251253.

4. Fukunaga, M., M. Sohnaka, and Y. Yanagihara. 1993. Analysis of Borrelia species associated with Lyme disease by rRNA gene restriction fragment length polymorphism. J. Gen. Microbiol. 139:1141-1146.

5. Fukunaga, M., Y. Takahashi, Y. Tsuruta, O. Matsushita, D. Ralph, M. McClelland, and M. Nakao. 1995. Genetic and phenotypic analysis of Borrelia miyamotoi sp. nov., isolated from the ixodid tick Ixodes persulcatus, the vector for Lyme disease in Japan. Int. J. Syst. Bacteriol. 45:804-810.

6. Higgines, D. G., A. J. Bleasby, and R. Fuchs. 1992. CLUSTAL V: improved software for multiple sequence alignment. Comput. Appl. Biosci. 8:189-191.

7. Joseph, R., and E. Canale-Parola. 1972. Axial fibrils of anaerobic spirochetes: ultrastructure and chemical characteristics. Arch. Mikrobiol. 81:146168 .

8. Katayama-Fujimura, Y., Y. Komatsu, H. Kuraishi, and T. Kaneko. 1984. Estimation of DNA base composition by high performance liquid chromatography of its nuclease P1 hydrolysate. Agric. Biol. Chem. 48:3167-3172.

9. Laemmli, U. K. 1970 . Cleavage of structural proteins during the assembly of the head of bacteriophage T4. Nature (London) 227:680-685.

10. Listgarten, M. A., and L. Helldén. 1978. Relative distribution of bacteria in clinically healthy and periodontally diseased sites in humans. J. Clin. Periodontol. 5:115-132.

11. Listgarten, M. A., and S. S. Socransky. 1965. Electron microscopy as an aid in the taxonomic differentiation of oral spirochetes. Arch. Oral Biol. 10:127138.

12. Loesche, W. J. 1988. The role of spirochetes in periodontal disease. Adv. Dent. Res. 2:275-283.

13. Loesche, W. J., S. A. Syed, E. Schmidt, and E. C. Morrison. 1985. Bacteria profiles of subgingival plaques in periodontitis. J. Periodontol. 56:447-456.

14. Marmur, J. 1961. A procedure for the isolation of deoxyribonucleic acid from microorganisms. J. Mol. Biol. 3:207-208.

15. Meyer, S. A., and K. H. Schleifer. 1978. Deoxyribonucleic acid reassociation in the classification of coagulase positive staphylococci. Arch. Microbiol. 117:183-188.

16. Miller, J. N., R. M. Smibert, and S. J. Norris. 1992. The genus Treponema, p. 3537-3559. In A. Balows, H. G. Trüper, M. Dworkin, W. Harder, and K.-H. Schleifer (ed.), The prokaryotes, 2nd ed. Springer-Verlag New York, Inc., New York, N.Y.

17. Nakamura, Y., T. Umemoto, Y. Nakatani, I. Namikawa, and A. Wadood. 1993. Common and specific antigens of several treponemes detected by polyclonal antisera against major cellular proteins. Oral Microbiol. Immunol. 8:288-294.
18. Nakatani, Y., T. Umemoto, Y. Nakamura, and I. Namikawa. 1994. Fibronectin-binding proteins of host-associated spirochetes. Jpn. J. Oral Biol. 36:330 334.

19. Nakazawa, F., and E. Hoshino. 1993. Immunological specificity of oral Eubacterium species. J. Gen. Microbiol. 139:2635-2640.

20. Nakazawa, F., and E. Hoshino. 1994. Genetic relationships among Eubacterium species. Int. J. Syst. Bacteriol. 44:787-790.

21. Ohta, K., K. K. Mäkinen, and W. L. Loesche. 1986. Purification and characterization of an enzyme produced by Treponema denticola capable of hydrolyzing synthetic trypsin substrates. Infect. Immun. 53:213-220.

22. Paster, B. J., F. E. Dewhirst, W. G. Weisberg, L. A. Tardoff, G. J. Fraser, R. B. Hespell, T. B. Stanton, L. Zablen, L. Mandelco, and C. R. Woese. 1991. Phylogenetic analysis of the spirochetes. J. Bacteriol. 173:6101-6109.

23. Riviere, G. R., K. S. Smith, N. Carranza, Jr., E. Tzagaroulaki, S. L. Kay, and M. Dock. 1995. Subgingival distribution of Treponema denticola, Treponema socranskii, and pathogen-related oral spirochetes: prevalence and relationship to periodontal status of sampled sites. J. Periodontol. 66:829-837.

24. Rosebury, T., and G. Foley. 1942. Isolation and pure cultivation of smaller mouth spirochetes by an improved method. Proc. Soc. Exp. Biol. Med. 47:368-374.

25. Simonson, L. G., C. H. Goodman, J. J. Bial, and H. E. Morton. 1988. Quantitative relationship of Treponema denticola to severity of periodontal disease. Infect. Immun. 56:726-728.

26. Smibert, R. M. 1984. Genus III. Treponema Schaudinn 1905, p. 49-57. In N. R. Krieg and J. G. Holt (ed.), Bergey's manual of systematic bacteriology, vol. 1. The Williams and Wilkins Co., Baltimore, Md.

27. Smibert, R. M. 1991. Anaerobic spirochetes, p. 572-578. In A. Balows, W. J. Hausler, Jr., K. L. Herrmann, H. D. Isenberg, and H. J. Shadomy (ed.) Manual of clinical microbiology, 5th ed. American Society for Microbiology, Washington, D.C.

28. Smibert, R. M., and J. A. Brunmeister. 1983. Treponema pectinovorum $\mathrm{sp}$. nov. isolated from humans with periodontitis. Int. J. Syst. Bacteriol. 33:852856.

29. Smibert, R. M., J. L. Johnson, and R. R. Ranney. 1984. Treponema socranskii sp. nov., Treponema socranskii subsp. socranskii subsp. nov., Treponema socranskii subsp. buccale subsp. nov., and Treponema socranskii subsp. paredis subsp. nov. isolated from the human periodontia. Int. J. Syst. Bacteriol. 34:457-462.

30. Stanton, T. B., N. S. Jensen, T. A. Casey, L. A. Tordoff, F. E. Dewhirst, and B. J. Paster. 1991. Reclassification of Treponema hyodysenteriae and Treponema innocens in a new genus, Serpula gen. nov., as Serpula hyodysenteriae comb. nov. and Serpula innocens comb. nov. Int. J. Syst. Bacteriol. 41:50-58.

31. Stanton, T. B. 1992. Proposal to change the genus designation Serpula to Serpulina gen. nov. containing the species Serpulina hyodysenteriae comb. nov. and Serpulina innocens comb. nov. Int. J. Syst. Bacteriol. 42:189-190.

32. Sutter, V. A., D. M. Citron, and S. M. Finegold. 1980. Wadsworth anaerobic bacteriology manual, 3rd ed. The C. V. Mosby Co., St. Louis, Mo.

33. Umemoto, T., and I. Namikawa. 1980. Electron microscopy of the spherical body of oral spirochetes in vitro. Microbiol. Immunol. 24:321-334.

34. Umemoto, T., and I. Namikawa. 1994. Binding of host-associated treponeme proteins to collagens and laminin: a possible mechanism of spirochetal adherence to host tissues. Microbiol. Immunol. 38:655-663.

35. Umemoto, T., I. Namikawa, and M. Yamamoto. 1984. Colonial morphology of treponemes observed by electron microscopy. Microbiol. Immunol. 28: 11-22.

36. Umemoto, T., I. Namikawa, H. Suido, and S. Asai. 1989. A major antigen on the outer envelope of a human oral spirochete, Treponema denticola. Infect. Immun. 57:2470-2474. 